Division of Geological \& Geophysical Surveys

GEOPHYSICAL REPORT 2002_15

PORTFOLIO OF AEROMAGNETIC AND RESISTIVITY MAPS OF THE BROAD PASS SURVEY, CENTRAL ALASKA

\author{
by \\ Laurel E. Burns \\ March 2002 \\ THIS REPORT HAS NOT BEEN REVIEWED FOR \\ TECHNICAL CONTENT (EXCEPT AS NOTED IN TEXT) OR FOR \\ CONFORMITY TO THE EDITORIAL STANDARDS OF DGGS.
}

Released by

STATE OF ALASKA

DEPARTMENT OF NATURAL RESOURCES

Division of Geological \& Geophysical Surveys

794 University Avenue, Suite 200

Fairbanks, Alaska 99709-3645 


\section{PORTFOLIO OF AEROMAGNETIC AND RESISTIVITY MAPS OF THE BROAD PASS AREA, SOUTHWESTERN BONNIFIELD MINING DISTRICT, CENTRAL ALASKA}

In the summer of 2001, the Alaska Division of Geologic \& Geophysical Surveys acquired airborne geophysical data about 304 square miles in the Healy quadrangle (figure 1). The data were acquired and processed under contract by Stevens Exploration Management, Corp. and their subcontractor, Fugro Airborne Surveys. Aeromagnetic and electromagnetic data were collected in July and August of 2001. The data were merged with the Chulitna airborne geophysical survey (DGGS and others, 1997) acquired by DGGS in summer 1997 southwest of the current survey. The new data were released March 2002 in the forms of maps and digital files.

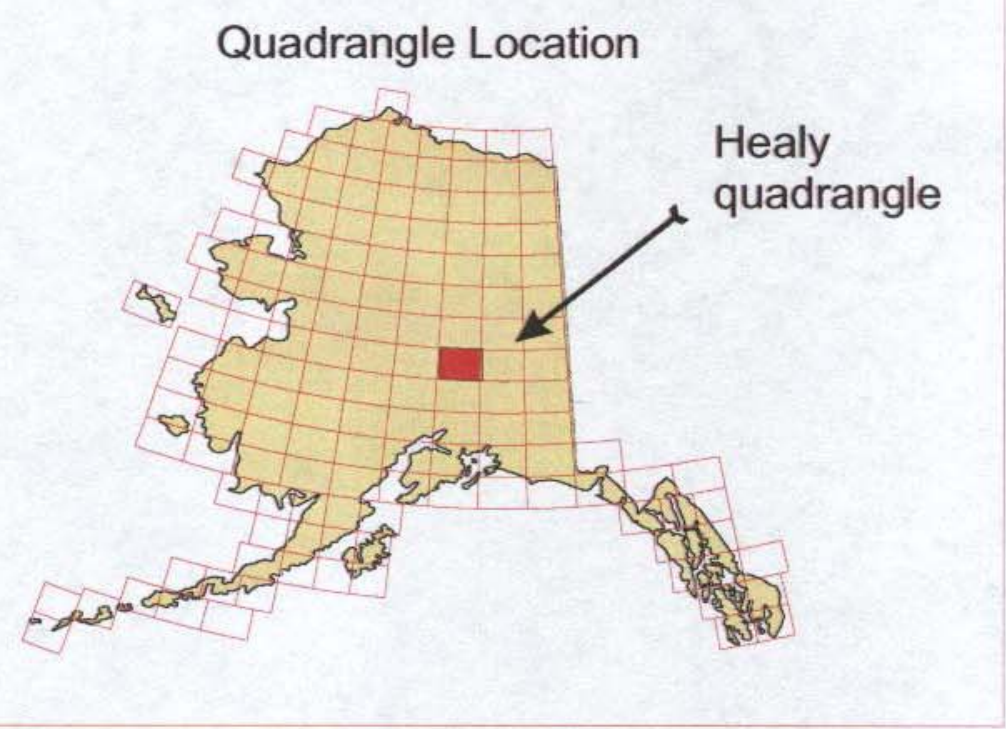

Figure 1. Location of Healy quadrangle.

This Geophysical Report (GPR) contains generalized information on data acquisition, data interpretation, publications, and data formats available for the Broad Pass survey. Page-size color maps of most of the data are also included. The contractor's report, GPR 2002_14, gives a more detailed interpretation of the data and a more complete description of the processing.

The acetate topography included with this portfolio should be used only for generalized locations. For accurate locations, the large scale geophysical maps or the computer files should be used. The area surveyed in 2001 includes parts of the Healy quadrangle (fig. 2).

Clients can request maps from this geophysical survey from the Alaska Division of Geological \& Geophysical Surveys. Ordering information and available maps are listed at the end of this portfolio. Some of the products are available at DNR's Public Information Center in Anchorage. Most of the maps in this portfolio are available from DGGS. Custom plots of variations of the data can be made at any scale at the DGGS office for a reasonable fee. 


\section{PRODUCTS AVAILABLE FROM THIS SURVEY}

Maps are available of the aeromagnetic, $7200 \mathrm{~Hz}$ coplanar resistivity data, and $900 \mathrm{~Hz}$ coplanar resistivity data. Most of the maps for the Broad Pass area were produced at 1:63,360 scale ( 1 inch = 1 mile, fig. 2$)$. Aeromagnetic maps with electromagnetic (EM) anomalies were produced at $1: 63,360$-scale with simplified EM symbols and $1: 31,680$-scale $(1$ inch $=1 / 2$ mile; fig. 3) with detailed EM symbols (1 inch $=1 / 2$ mile; fig. 3 ).

Figure 2. Index map showing area of new data acquisition (red outline) and older Chulitna survey area (blue outline). Data for hachured area included on the map sheets. Gridded and vector magnetic and electromagnetic data included on the CD-ROM publications GPR 2002_12 and GPR 2002_13 included data for the old and new surveys. Line data included on GPR 2002_2 includes only the new data. All 63,360-scale maps fit on one sheet.

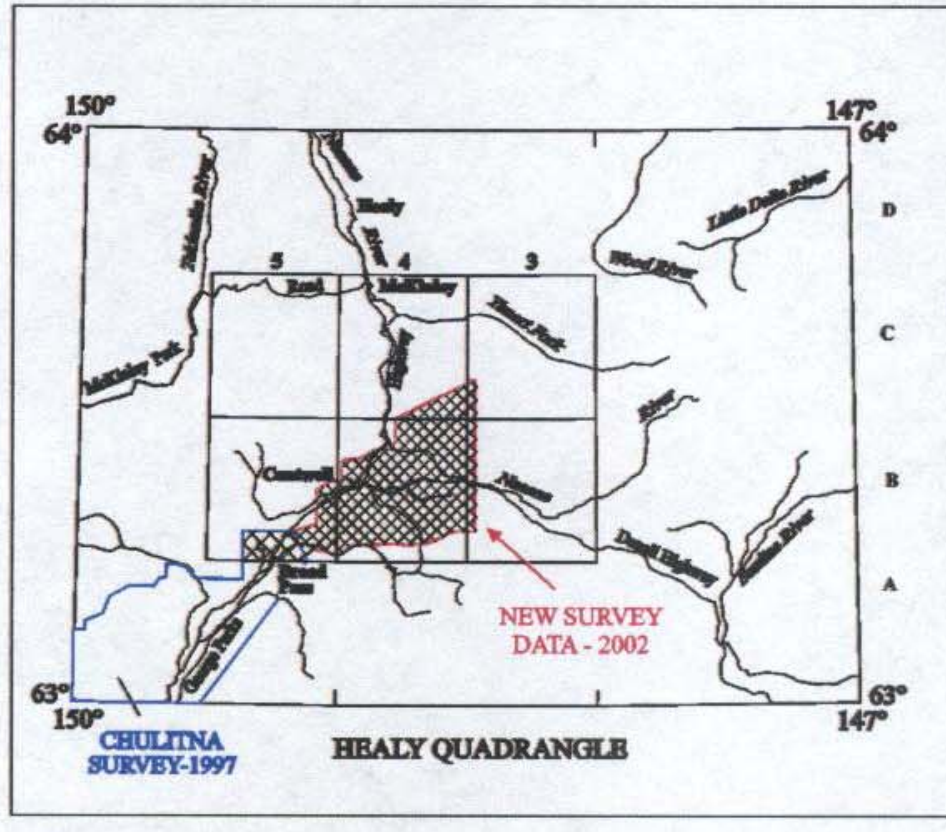

Figure 3. Index map for aeromagnetic maps available at 1:31,680 (1 inch $=1 / 2$ mile) scale. Only aeromagnetic maps with detailed EM anomalies are available at this scale. New survey area (red outline) shows area of new data acquisition. Two map sheets (marked 2a and 2b) are used to cover the area at 31,680 -scale.

Three CD-ROMS were produced for this survey. GPR 2002_11 contains plot files in $\mathrm{HPGL} / 2$ format of the 13 maps produced from this survey. The plot files were produced with Hewlett Packard Designjet 2500 printer driver version 4.61. GPR 2002_12 contains the processed line data, gridded data (magnetic data, $900 \mathrm{~Hz}, 7200$ $\mathrm{Hz}$, and $56,000 \mathrm{~Hz}$ coplanar apparent resistivity data, and a digital terrain model)

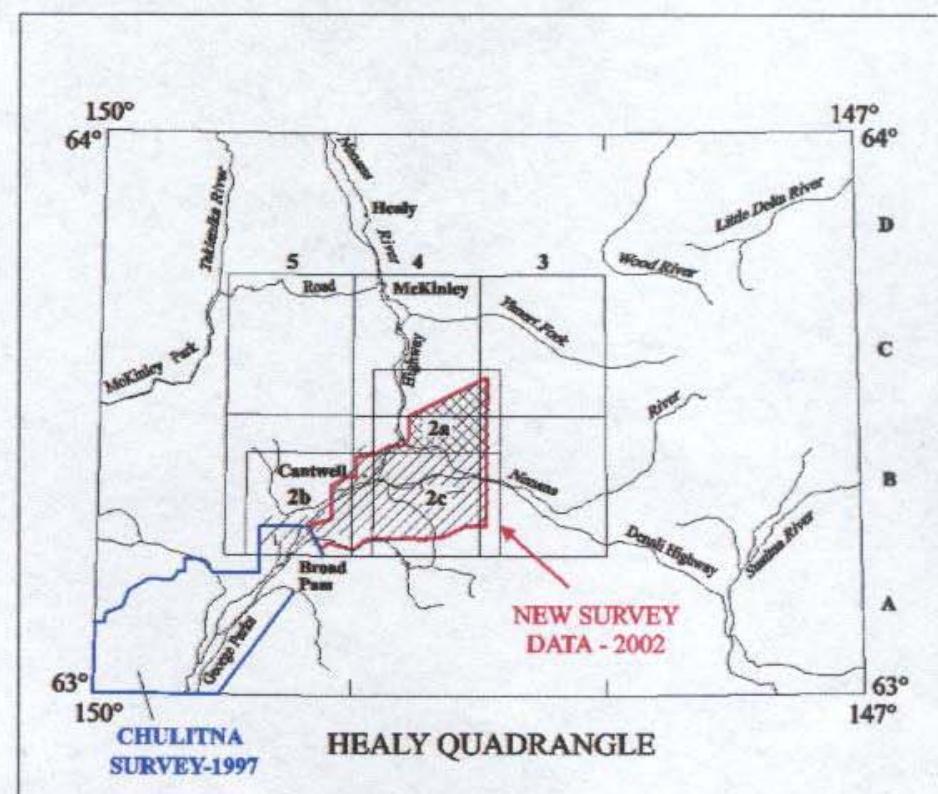

with associated data contour files, and detailed electromagnetic anomalies. The processed line data is in Geosoft Ascii format, the gridded data are in both Geosoft Ascii and Geosoft binary format, and the vector files are in Autocad version 14 dxf files. GPR 2002_13 contains the gridded data in Geosoft binary format ony with associated data contour files, and detailed electromagnetic anomalies.

\section{Survey history, instrumentation, \& data processing}

The following indented section describing the instrumentation and processing is modified from the metadata included on the CD-ROMS. 
The 2002 airborne geophysical data were acquired with a DIGHEM(V) Electromagnetic (EM) system and a Scintrex cesium magnetometer. Both were flown at a height of 100 feet. In addition, the survey recorded data from a radar altimeter, GPS navigation system, $50 / 60 \mathrm{~Hz}$ monitors and video camera. Flights were performed with an AS350B-2 Squirrel helicopter at a mean terrain clearance of 200 feet along NW-SE (340 degrees) survey flight lines with a spacing of one quarter mile. Tie lines were flown perpendicular to the flight lines at intervals of approximately 3 miles.

An Ashtech GG24 NAVSTAR/GLONASS Global Positioning System was used for navigation. The helicopter position was derived every 0.5 seconds using post-flight differential positioning to a relative accuracy of better than $5 \mathrm{~m}$. Flight path positions were projected onto the Clarke 1866 (UTM zone 6) spheroid, 1927 North American datum using a central meridian (CM) of 147 degrees, a north constant of 0 and an east constant of 500,000 .

\section{Total Field Magnetics:}

The total magnetic field data were acquired with a sampling interval of 0.1 seconds, and were (1) corrected for diurnal variations by subtraction of the digitally recorded base station magnetic data, (2) leveled to the tie line data, and (3) interpolated onto a regular $100 \mathrm{~m}$ grid using a modified Akima (1970) technique. The regional variation (or IGRF gradient, 2000, updated to August 2001) was removed from the leveled magnetic data. The aeromagnetic data were then merged with the IGRFcorrected aeromagnetic data from the Salcha River-Pogo survey (published 2000) using the line data. The merged aeromagnetic data are interpolated onto a regular $100 \mathrm{~m}$ grid using a modified Akima (1970) technique. Akima, H., 1970, A new method of interpolation and smooth curve fitting based on local procedures: Journal of the Association of Computing Machinery, v. 17, no. 4, p. 589-602.

\section{Resistivity:}

The EM inphase and quadrature data are drift corrected using base level data collected at high altitude (areas of no signal). Along-line filters are applied to the data to remove spheric spikes. The data are inspected for variations in phase, and a phase correction is applied to the data if necessary. Resistivities are then calculated from the inphase and quadrature data for all frequencies based on a pseudo-layer half-space model. Manual leveling of the inphase and quadrature of each coil pair, based on the resistivity data and comparisons to the data from the other frequencies, is performed. Automated micro-leveling is carried out in areas of low signal. The resistivity data were then merged with the resistivity data from the Salcha River-Pogo survey released (published 2000) using the line data. The resistivity data are then interpolated onto a regular $100 \mathrm{~m}$ grid using a modified Akima (1970) technique. The resulting grids are subjected to a $3 \times 3$ hanning filter before contouring and map production. Akima, H., 1970, A new method of interpolation and smooth curve fitting based on local procedures: Journal of the Association of Computing Machinery, v. 17, no. 4, p. 589-602. Fraser, D.C., 1978, Resistivity mapping with an airborne multicoil electromagnetic system: Geophysics, v. 43, p.144-172.

Akima, H., 1970, A new method of interpolation and smooth curve fitting based on local procedures: Journal of the Association of Computing Machinery, v. 17, no. 4, p. 589-602.

\section{Generalized information about aeromagnetic, electromagnetic, and radiometric data}

\section{Magnetic data}

The magnetometer is a passive instrument that measures the earth's magnetic field in nanoTeslas (nT). Rocks with high magnetic susceptibilities (measured in SI units) locally attenuate or dampen these magnetic signals producing the relative highs and lows. Iron-rich magnetic minerals such as magnetite, ilmenite, and pyrrhotite have the highest magnetic susceptibility. These minerals commonly occur in mafic volcanic rocks (such as basalt), mafic and ultramafic plutonic rocks (such as serpentinite, 
clinopyroxenite, and gabbro), some skarns, and in some other geologic units. Rocks with low to no iron tend to produce little variation in the magnetic signal. These include silicic volcanic rocks (rhyolites), silicic plutonic rocks (granites), and most sedimentary rocks (for example, limestone, sandstone, and shale). Some iron rich minerals - such as pyrite - are not magnetic and do not produce a magnetic signal.

Different types of ore deposits have different magnetic signatures. A bedrock gold deposit associated with the top of a granitic pluton would likely be an aeromagnetic low whereas a magnetite-bearing gold skarn would be an aeromagnetic high. A gold deposit hosted by a low-angle (thrust) fault has a different signature than one hosted by a high-angle fault.

Figures $4 \mathrm{a}$ show the aeromagnetic data for the Broad Pass and the Chulitna survey area. The high values (in $\mathrm{nT}$ ) are purple and orange and indicate appreciably magnetic rocks. The low values are the blues and greens. Figures $4 \mathrm{~b}$ shows the aeromagnetic data for just the Broad Pass area. A gradual change in color indicates a gradual change in the magnetic field strength. This can be caused by either a gradual change in magnetic susceptibility of rocks near the surface, the gradual burial of a rock unit of relatively constant magnetic susceptibility, or the introduction of a new unit at depth. Conversely, an abrupt change in color indicates an abrupt change in the magnetic susceptibility. This is caused by juxtaposing two rock units with very different magnetic susceptibilities such as is the case with faults, volcanic dikes, or some mineralized zones. Faults can be inferred on aeromagnetic maps from linear or curvilinear features composed of discontinuous aeromagnetic highs or lows.

Figures $4 \mathrm{c}$ show the Broad Pass aeromagnetic data presented respectively as "color shadow" maps where a simulated light source is shown on the three-dimensional data. The higher values appear bright like mountaintops struck by sunlight. The light source can be rotated in a complete circle with $0^{\circ}$ (north) clockwise to $180^{\circ}$ (south) and back to $360^{\circ}$ (north). Shadow maps can enhance structures, such as faults, intrusions, and the trend of stratigraphic layers.

\section{Resistivity data}

The electromagnetic (EM) system is an active instrument that measures the resistivity of the rocks below it by sending out electromagnetic signals at different frequencies and recording the signals that are returned from the earth. The high values (measured in ohm-m) are indicative of resistive (low conductivity) rocks, such as quartzite. Low resistivity (high conductivity) values are present for bedrock conductors (water-saturated clays, graphite, concentrations of certain sulfides, some alteration halos), conductive overburden (water-saturated zones), and cultural sources (e.g. powerlines). The main conductive minerals are graphite, most sulfides, (but not sphalerite), and water-saturated clays. Rocks hydrothermally altered to clay minerals also are conductive. Some faults will show up very well on the resistivity maps, because they either offer a conduit for ground water or they separate rocks with markedly different resistivities.

The EM instrument (bird) contains 5 or more transmitting coils in front and 5 matching (paired) receiver coils in the rear. Three of these pairs are coplanar - the axes of the coils are perpendicular to the long axis of the bird. Two of these pairs are coaxial - the axes of the coils are parallel to the long axis of the bird. These two major geometric configurations, coplanar and coaxial, record different information about the conductivity of the rocks below. Coplanar coils emphasize horizontal and flat lying conductive units. Coaxial coils emphasize vertical to near vertical conductive units.

The coplanar resistivity data are shown in Figures $5 \mathrm{a}, 5 \mathrm{~b}, 6$, and-7. resistivity maps are produced from the EM coplanar coil pairs, and emphasize horizontal or near horizontal units and structures. Since ground penetration correlates inversely with frequency, the $56,000 \mathrm{~Hz}$ reflects very near surface rocks and the $900 \mathrm{~Hz}$ adds the influence of deeper rocks in general. The $7200 \mathrm{~Hz}$ in general reflects rocks between the two extremes. However, the depth of penetration is variable depending on the resistivity of the rocks the signal is passing through.

EM anomalies are shown with both the 1:63,360 and 1:31,680 scale magnetic maps. EM anomalies are 
derived from the coaxial coil pairs, which emphasize vertically- or near-vertically-dipping "discrete" bedrock conductors. These EM anomalies are shown as circular symbols along flight lines with the aeromagnetic contours. On the 1:63,360 scale maps, anomalies are subdivided into those with 1) a signal strength greater than 50 siemens, 2) a signal strength less than 50 siemens, and 3) weak conductivity associated with an EM magnetite response. Questionable (or possible) anomalies are also noted.

More detailed interpretations for the electromagnetic anomalies are shown on the 1:31,680 scale aeromagnetic maps. In these maps, the EM anomaly is shown as a symbol that denotes more information about signal strength and the anomaly source than on the 1:63,360 maps. Instead of two signal strengths (greater than or less than 50 siemens) shown on the 1:63,360 maps, signal strength on the 1:31,680 maps is broken into seven subdivisions (e.g. 5-10 siemens, 1-5 siemens, etc). In addition, potential sources shown for each symbol include 1) bedrock conductors, 2) narrow bedrock conductors ("thin dike"), 3) conductive covers ("horizontal thin sheet"), 4) combination including broad conductive rock units, deep conductive weathering, and thick conductive cover, 5) edge of broad conductor, and 6) culture. This information is also available on the CD-ROMS. The project report, GPR 2002-14, gives a more detailed discussion of these EM anomalies.

\section{DGGS PUBLICATIONS PRODUCED FOR THE BROAD PASS SURVEY AREA}

Bold font is used below to highlight the differences between the maps.

\section{AEROMAGNETIC MAPS}

GPR 2002_1_1a. Total magnetic field of the southeastern extension of Broad Pass survey, southwestern Bonnifield mining district, central Alaska, 1 sheet, scale 1:63,360. Topography included. Fullcolor plot from electronic file, $600 \mathrm{dpi}$.

GPR 2002_1_1b. Total magnetic field of the southeastern extension of Broad Pass survey, southwestern Bonnifield mining district, central Alaska, 1 sheet, scale 1:63,360. Magnetic contours and section lines included. Full-color plot from electronic file, $600 \mathrm{dpi}$.

GPR 2002_1_1c. Color shadow magnetic map of the southeastern extension of Broad Pass survey, southwestern Bonnifield mining district, central Alaska, 1 sheet, scale 1:63,360. Full-color plot from electronic file, 600 dpi.

GPR 2002_1_1d. Total magnetic field and electromagnetic anomalies of the southeastern extension of Broad Pass survey, southwestern Bonnifield mining district, central Alaska, 1 sheet, scale 1:63,360. Magnetic contours, simplified electromagnetic anomalies, and section lines included. Black and white plot from electronic file, $600 \mathrm{dpi}$.

GPR 2002_1_2a. Total magnetic field and detailed electromagnetic anomalies of the southeastern extension of Broad Pass survey, southwestern Bonnifield mining district, central Alaska, 1 sheet, scale 1:31,680 (parts of Big Delta B-1 and B-2 quadrangles). Magnetic contours, detailed electromagnetic anomalies, and topography included. Black and white plot from electronic file, 600 dpi.

GPR 2002_1_2b. Total magnetic field and detailed electromagnetic anomalies of the southeastern extension of Broad Pass survey, southwestern Bonnifield mining district, central Alaska, 1 sheet, scale 1:31,680 (parts of Big Delta B-1 and B-2 quadrangles). Magnetic contours, detailed 
electromagnetic anomalies, and topography included. Black and white plot from electronic file, $600 \mathrm{dpi}$.

\section{RESISTIVITY MAPS}

GPR 2002_11_3a. $7200 \mathrm{~Hz}$ coplanar resistivity of the southeastern extension of Broad Pass survey, southwestern Bonnifield mining district, central Alaska, 1 sheet, scale 1:63,360. Topography included. Full-color plot from electronic file, $600 \mathrm{dpi}$.

GPR 2002_11_3b. $7200 \mathrm{~Hz}$ coplanar resistivity of the southeastern extension of Broad Pass survey, southwestern Bonnifield mining district, central Alaska, 1 sheet, scale 1:63,360. Resistivity contours and section lines included. Full-color plot from electronic file, $600 \mathrm{dpi}$.

GPR 2002_11_3c. $7200 \mathrm{~Hz}$ coplanar resistivity of the southeastern extension of Broad Pass survey, southwestern Bonnifield mining district, central Alaska, 1 sheet, scale 1:63,360. Resistivity contours and section lines included. Black and white plot from electronic file, $600 \mathrm{dpi}$

GPR 2002_11_4a. $900 \mathrm{~Hz}$ coplanar resistivity of the southeastern extension of Broad Pass survey, southwestern Bonnifield mining district, central Alaska, 1 sheet, scale 1:63,360. Topography included. Full-color plot from electronic file, 600 dpi.

GPR 2002_11_4b. $900 \mathrm{~Hz}$ coplanar resistivity of the southeastern extension of Broad Pass survey, southwestern Bonnifield mining district, central Alaska, 1 sheet, scale 1:63,360. Resistivity contours and section lines included. Full-color plot from electronic file, 600 dpi.

GPR 2002_11_4c. $900 \mathrm{~Hz}$ coplanar resistivity of the southeastern extension of Broad Pass survey, southwestern Bonnifield mining district, central Alaska, 1 sheet, scale 1:63,360. Resistivity contours and section lines included. Black and white plot from electronic file, 600 dpi.

\section{DIGITAL FILES, PROJECT REPORT, PORTFOLIO, AND FLIGHT LINES}

GPR 2002_11_5a. Flight lines of the southeastern extension of Broad Pass survey, southwestern Bonnifield mining district, central Alaska, 1 sheet, scale 1:63,360. Topography included. Black and white plot from electronic file, $600 \mathrm{dpi}$.

GPR 2002_11. Plot files of the airborne geophysical survey data of the southeastern extension of Broad Pass survey, southwestern Bonnifield mining district, central Alaska. 1 CD-ROM set. Contains 13 maps listed below as GPR2002_1_xy in prn printer file format made with an HP Designjet $2500 \mathrm{HPGL} / 2$ printer driver $\mathbf{v}$.61. Check for printer compatability.

GPR 2002_12. Line, gridded, and vector data of airborne geophysical survey data for the southeastern extension of Broad Pass survey, southwestern Bonnifield mining district, central Alaska. 2 CDROM set. Line data in ASCII format; gridded data in Geosoft format; vector files in Autocad 14 dxf files.

GPR 2002_13. Gridded and vector data of airborne geophysical survey data for the southeastern extension of Broad Pass survey, southwestern Bonnifield mining district, central Alaska. 1 CDROM set. Gridded data in Geosoft format; vector files in Autocad 14 dxf files.

GPR 2002_14. Project report of the airborne geophysical survey of of Broad Pass survey, southwestern Bonnifield mining district, central Alaska, by Ruth Pritchard, Fugro Airborne Surveys, 2002, scale 1:63,360. 
GPR 2002_15. Portfolio of aeromagnetic and resistivity maps of the southeastern extension of Broad Pass survey, southwestern Bonnifield mining district, central Alaska. Includes color and shadow maps. Maps fit 81/2" x 11" sheet.

\section{SELECTED REFERENCES FOR THE BROAD PASS GEOPHYSICAL SURVEY AND NEARBY AREA}

Current links to online data are provided. DGGS data is either in PDF format for reports or Mr. SID format for maps.

\section{GEOPHYSICAL DATA}

Barnes, David F., 1977, Preliminary Bouguer gravity map of central Alaska, U.S. Geological Survey Open-File Report, 77-0168-C.

Burns, Laurel E., 1997, Portfolio of aeromagnetic and resistivity maps of the Chulitna mining district: Alaska Division of Geological \& Geophysical Surveys, Public Data File 97-07: http://wwwdggs.dnr.state.ak.us/scan2/pdf97/text/PDF97-07.PDF 13 p., .PDF format (10435 KB).

Division of Geologic \& Geophysical Surveys, CGG Dighem, and W.G.M., Inc., 1997, CD-ROM digital archive files of 1996 survey data for Chulitna \& Petersville mining district, Alaska.: Alaska Division of Geological \& Geophysical Surveys, Public data File PDF 97-5. Many individual magnetic, resistivity, and radiometric maps are published by DGGS for this survey and are not repeated here.

Ruth Pritchard, Division of Geologic \& Geophysical Surveys, CGG Dighem, and W.G.M., Inc., 1997, Project Report for the Chulitna and Petersville Survey Areas: Alaska Division of Geological \& Geophysical Surveys, Public data File PDF 97-8. http://wwwdggs.dnr.state.ak.us/scan2/pdf97/text/PDF97-08.PDF

Saltus, R.W., and Simmons, G.C., 1997, Composite and Merged Aeromagnetic Data for Alaska: A Website for Distribution of Gridded Data and Plot Files: U.S. Geological Survey Open File Report OFR 97-520. http://greenwood.cr.usgs.gov/pub/open-file-reports/ofr-97-0520/alaskamag.html

\section{GEOLOGIC DATA}

Albanese, Mary D., Turner, Donald L., 1980, 40K-40Ar ages from rhyolite of Sugar Loaf Mountain, central Alaska Range: Implications for offset along the Hines Creek strand of the Denali Fault system: in Short Notes on Alaskan Geology 1979-1980: Alaska Division of Geological \& Geophysical Surveys, Geologic Report 63B: http://wwwdggs.dnr.state.ak.us/scan1/gr/text/GR63.PDF 32 p., .PDF format (984 KB).

Bowers, Peter M., 1979, The Cantwell ash bed, a Holocent tephra in the central Alaska Range: in Short Notes on Alaskan Geology - 1978: Alaska Division of Geological \& Geophysical Surveys, Geologic Report 61E: http://wwwdggs.dnr.state.ak.us/scan1/gr/text/GR61.PDF 41 p., .PDF format (1349 KB).

Clautice, K.H., 1987, Rock samples analyses (1987): Circle, Fairbanks, Healy, and Kantishna areas: Alaska Division of Geological \& Geophysical Surveys, Public Data File 87-34: http://wwwdggs.dnr.state.ak.us/scan2/pdf87/text/PDF87-34.PDF 67 p., .PDF format (2997 KB).

Clautice, K.H., Newberry, R.J., Blodgett, R.B., Bundtzen, T.K., Gage, B.G., Harris, E.E., Liss, S.A., Miller, M.L., Pinney, D.S., Reifenstuhl, R.R., Clough, J.G., Stone, D.B., Whalen, M.T., 1999, Preliminary geologic map of the Healy A-6 Quadrangle, southcentral Alaska: Alaska Division of Geological \& Geophysical Surveys, Public Data File 99-24A: http://wwwdggs.dnr.state.ak.us/scan2/pdf99/text/PDF99-24A.PDF29 p., .PDF format (802 KB).

Clautice, K.H., Newberry, R.J., Blodgett, R.B., Bundtzen, T.K., Gage, B.G., Harris, E.E., Liss, S.A., Miller, M.L., Reifenstuhl, R.R., Clough, J.G., Pinney, D.S., Stone, D.B., Whalen, M.T., 1999, Preliminary interpretive bedrock geologic map of the Healy A-6 Quadrangle, southcentral Alaska: Alaska Division of Geological \& Geophysical Surveys, Public Data File 99-24B: Report, 27 p., .PDF format (761 KB).

Clautice, K.C., Newberry, R.J., Pinney, D.S., Blodgett, R.B., Bundtzen, T.K., Gage, B.G., Harris, E.E., Liss, S.A., Miller, M.L., Reifenstuhl, R.R., and Clough, J.G, 2001, Geologic map of the Chulitna region, Southcentral Alaska: Alaska Division of Geological \& Geophysical Surveys, Report of Investigations RI 2001_1B .

Foley, J.Y., Burns, L.E., Schneider, C.L., Forbes, R.B., 1989, Preliminary report of platinum group element 
occurrences in Alaska: Alaska Division of Geological \& Geophysical Surveys, Public Data File 89-20: http://wwwdggs.dnr.state.ak.us/scan2/pdf89/text/PDF89-20.PDF 33 p., .PDF format (436 KB).

Gage, B.G., Chu, P.S., Liss, S.A., and Clautice, K.H., 1998, Preliminary geochemical and major oxide data: Chulitna project, Healy A-6 Quadrangle and nearby areas (1997 and 1998 data): Alaska Division of Geological \& Geophysical Surveys, Public Data File 98-36A: http://wwwdggs.dnr.state.ak.us/scan2/pdf98/text/PDF98-36A.PDF 48 p., .PDF format (1841 KB) http:/wwwdggs.dnr.state.ak.us/scan2/pdf98/oversized/PDF98-36A-SH1.SID , Sheet 1, Geochemical sample locality map - Healy A-6 Quadrangle \& surrounding area, scale 1:63,360, .SID format (4842 KB). http://wwwdggs.dnr.state.ak.us/scan2/pdf98/oversized/PDF98-36A-SH2.SID Sheet 2, Major oxide sample locality map - Healy A-6 Quadrangle \& surrounding area, scale 1:63,360, .SID format (4676 KB).

Hawley, C.C. and Clark, Allen L., 1973, Geology and mineral deposits of the Chulitna-Yentna Mineral Belt, Alaska: U.S. Geological Survey Professional Paper 758-A.

Hickman, R.G., Craddock, Campbell, 1976, Geologic map of the central Healy Quadrangle: Alaska Division of Geological \& Geophysical Surveys, Alaska Open File Report 95: http://wwwdggs.dnr.state.ak.us/scan1/gr/text/GR47.PDF, Geologic map of Central Healy Quadrangle, Alaska, scale $1: 63,360$, .SID format $(5568 \mathrm{~KB})$.

http://wwwdggs.dnr.state.ak.us/scan1/aof/oversized/AOF095-SH2.SID Geologic map of West Central Healy Quadrangle, Alaska, scale 1:63,360, .SID format (6779 KB).

http://wwwdggs.dnr.state.ak.us/scanl/aof/oversized/AOF095-SH3.SID Serial structural cross sections - Healy Quadrangle, Alaska, scale 1:63,360,.SID format (1667 KB).

Hickman, R.G., Craddock, Campbell, 1976, Mineral occurrences near Cantwell, southcentral Alaska: Alaska Division of Geological \& Geophysical Surveys, Special Report 13: http://wwwdggs.dnr.state.ak.us/scan1/sr/text/SR13.PDF 7 p., .PDF format (617 KB).

Land Information Sect., 1997, Land status and mining claims for Chulitna geophysical area, Alaska. Version 1.1: Alaska Division of Geological \& Geophysical Surveys, Public Data File 97-32: http://wwwdggs.dnr.state.ak.us/scan2/pdf97/oversized/PDF97-32-SH1.SID Land status and mining claims for Chulitna Geophysical Area, Alaska, .SID format (15419 KB).

Shepard, J.G., 1925, The Broad Pass Mining District: Alaska Territorial Department of Mines, Miscellaneous Report 67-03: http://wwwdggs.dnr.state.ak.us/scan1/mr/text/MR067-03.PDF 2 p., .PDF format (360 KB).

Shepard, J.G., 1925, Golden zone property (Wells Brothers, Bryn Mawr Creek): Alaska Territorial Department of Mines, Prospect Evaluation 67-01: http://wwwdggs.dnr.state.ak.us/scan1/pe/text/PE067-01.PDF 10 p., .PDF format (351 KB).

Sherwood, K.W., Craddock, Campbell, 1979, General geology of the central Alaska Range between the Nenana River and Mount Deborah: Alaska Division of Geological \& Geophysical Surveys, Alaska Open File Report 116: http://wwwdggs.dnr.state.ak.us/scanl/aof/text/AOF116.PDF 24 p., .PDF format (548 KB). AOF116-SHI, Geologic map of Nenana River and Yanert Fork Area - Central Alaska Range, Alaska, scale $1: 63,360$, .SID format $(5208 \mathrm{~KB})$.

http://wwwdggs.dnr.state.ak.us/scan1/aof/oversized/AOF116-SH1.SID Plate 2, Geologic map of the Wood River, Yanert Glacier and Gillam Glacier Areas, Central Alaska Range, Alaska, scale 1:63,360, .SID format (7184 KB).

http://wwwdggs.dnr.state.ak.us/scan1/aof/oversized/AOF116-SH3.SID Plate 3, Serial structural cross sections, Staff,

Stevens, Donald L., 2001, The Alaska Resource Data Files, Healy Quadrangle, U.S. Geological Survey Open-File Report 01-109. http://ardf.wr.usgs.gov/quads/html/Healy.html

Stewart, B.D., 1925, Mining tributary to the Alaska railroad: Alaska Territorial Department of Mines, Miscellaneous Report 195-09: http://wwwdggs.dnr.state.ak.us/scanl/mr/text/MR195-09.PDF 32 p., .PDF format (637 KB).

Swainback, R.C., Smith, T.E., Turner, D.L., 1977, Geology and K-Ar age of mineralized intrusive rocks from the Chulitna mining district, central Alaska: in Short Notes on Alaskan Geology - 1977: Alaska Division of Geological \& Geophysical Surveys, Geologic Report 55F: http://wwwdggs.dnr.state.ak.us/scanl/gr/text/GR55.PDF 50 p., .PDF format (1659 KB).

Thorson, Robert M., 1979, Recurrent Late Quaternary faulting near Healy, Alaska: in Short Notes on Alaskan Geology - 1978: Alaska Division of Geological \& Geophysical Surveys, Geologic Report 61C: http://wwwdggs.dnr.state.ak.us/scan1/gr/text/GR61.PDF 41 p., .PDF format (1349 KB). 
Thurmond, F.L., 1918, Report on Ready Cash Group, Ohio River, Broad Pass Region: Alaska Territorial Department of Mines, Miscellaneous Report 67-01: http://wwwdggs.dnr.state.ak.us/scan1/mr/text/MR06701.PDF 8 p., .PDF format (423 KB).

Townsend, H.H., 1926, Geological sketches and assay returns of prospects examined along the Alaska Railroad: Alaska Territorial Department of Mines, Itinerary Report 66-02: http://wwwdggs.dnr.state.ak.us/scanl/mr/text/MR067-01.PDF 9 p., .PDF format (5629 KB).

Townsend, H.H., 1925, Assay returns: Alaska Territorial Department of Mines, Itinerary Report 195-48: http://wwwdggs.dnr.state.ak.us/scanl/ir/text/IR195-48.PDF 17 p., .PDF format (286 KB).

Warfield, R.S., 1954, Cantwell manganese deposit, Bonnifield District: Alaska Territorial Department of Mines, Miscellaneous Report 67-08:

http://wwwdggs.dnr.state.ak.us/scan1/mr/text/MR067-08.PDF 9 p., .PDF format (885 KB). http://wwwdggs.dnr.state.ak.us/scan1/mr/oversized/MR067-08-SH1.SID Figure 2, Plan map Cantwell Manganese deposit, scale 1:50, .SID format (1602 KB).

Wiltse, M.A., 1990, Detailed geology reconnaissance traverse of upper Dry Creek, Healy Quadrangle, Alaska: Alaska Division of Geological \& Geophysical Surveys, Public Data File 90-11: http://wwwdggs.dnr.state.ak.us/scan2/pdf90/oversized/PDF90-11-SH1.SID Detailed geologic reconnaissance traverse of Upper Dry Creek, Healy Quadrangle, Alaska, scale 1:12,000, .SID format (4238 KB).

Wiltse, M.A., 1991, National uranium resource evaluation (NURE) geochemical data for stream and lake sediment samples, Alaska, Healy Quadrangle: Alaska Division of Geological \& Geophysical Surveys, Public Data File 91220:

http://wwwdggs.dnr.state.ak.us/scan2/pdf91/text/PDF91-220.PDF 33 p., .PDF format (600 KB).

Zeigler, G.E., 1940, Observations at the Healy, Colorado, and Eska properties: Alaska Territorial Department of Mines, Itinerary Report 194-02:

http://wwwdggs.dnr.state.ak.us/scan1/ir/text/IR194-02.PDF 2 p., .PDF format (242 KB). 
THIS PAGE INTENDED TO BE PRINTED ON CLEAR ACETATE/MYLAR

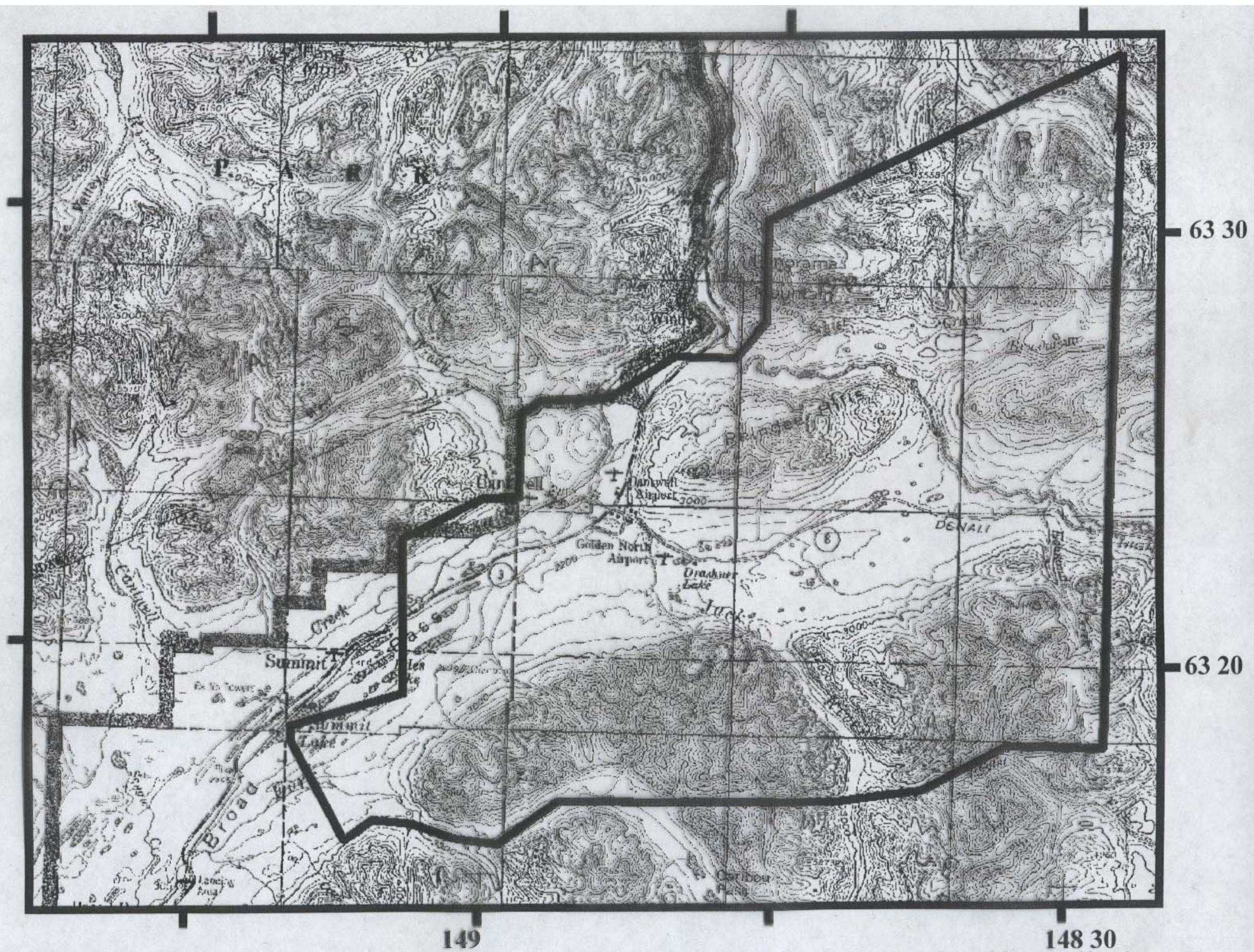

Topography for the Broad Pass area shown in figures $4 \mathrm{~b}, 5 \mathrm{~b}, 6$, and 7 in GPR 2002_15. This topography should only be used for general locations. 


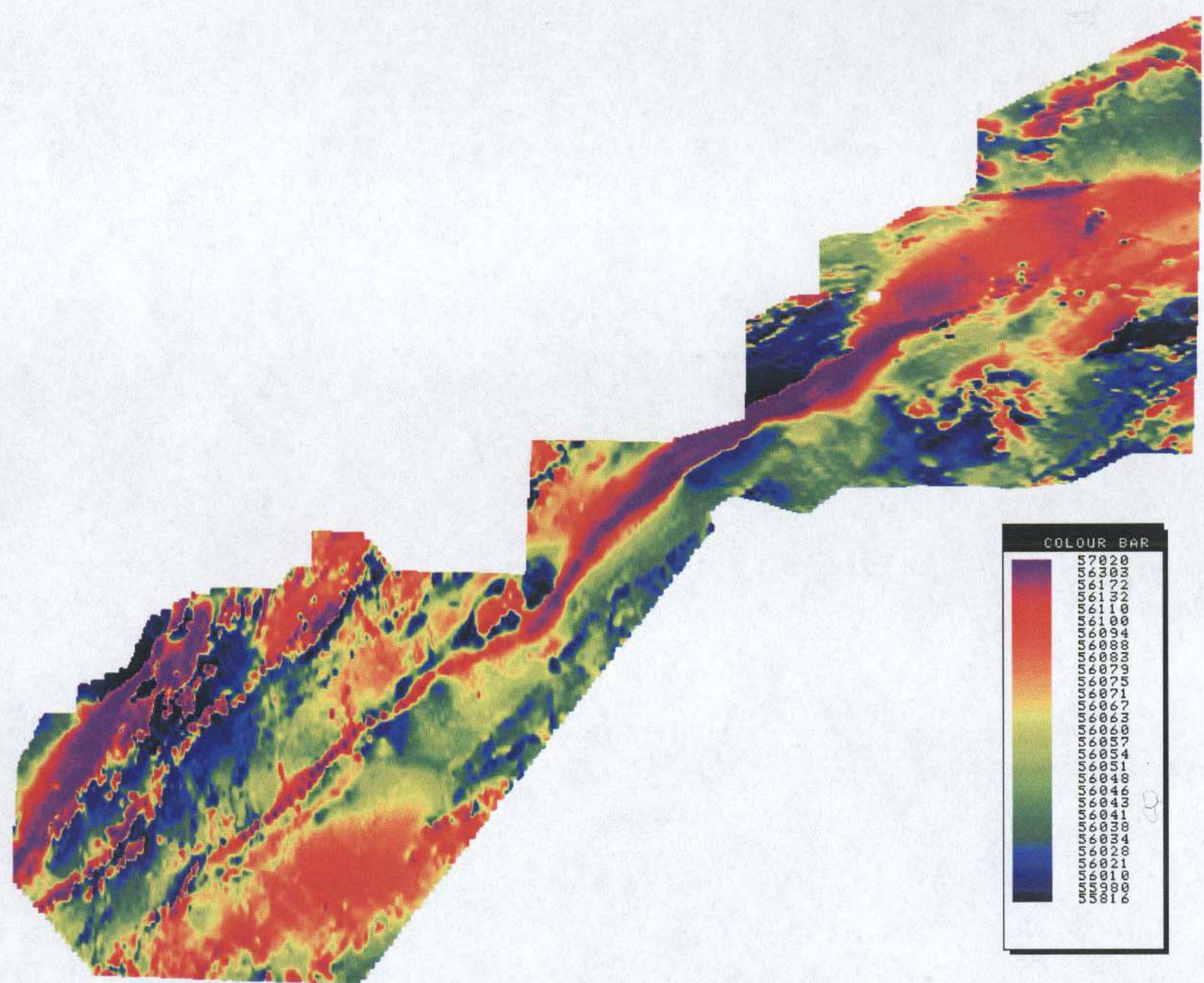

Figure 4a. Total field magnetics of the southeastern extension of the Broad Pass and Chulitna survey area. Magnetic units are in nT. Color scheme is an equal area distribution. In this techniques the image contains equal or nearly equal areas of each color. 


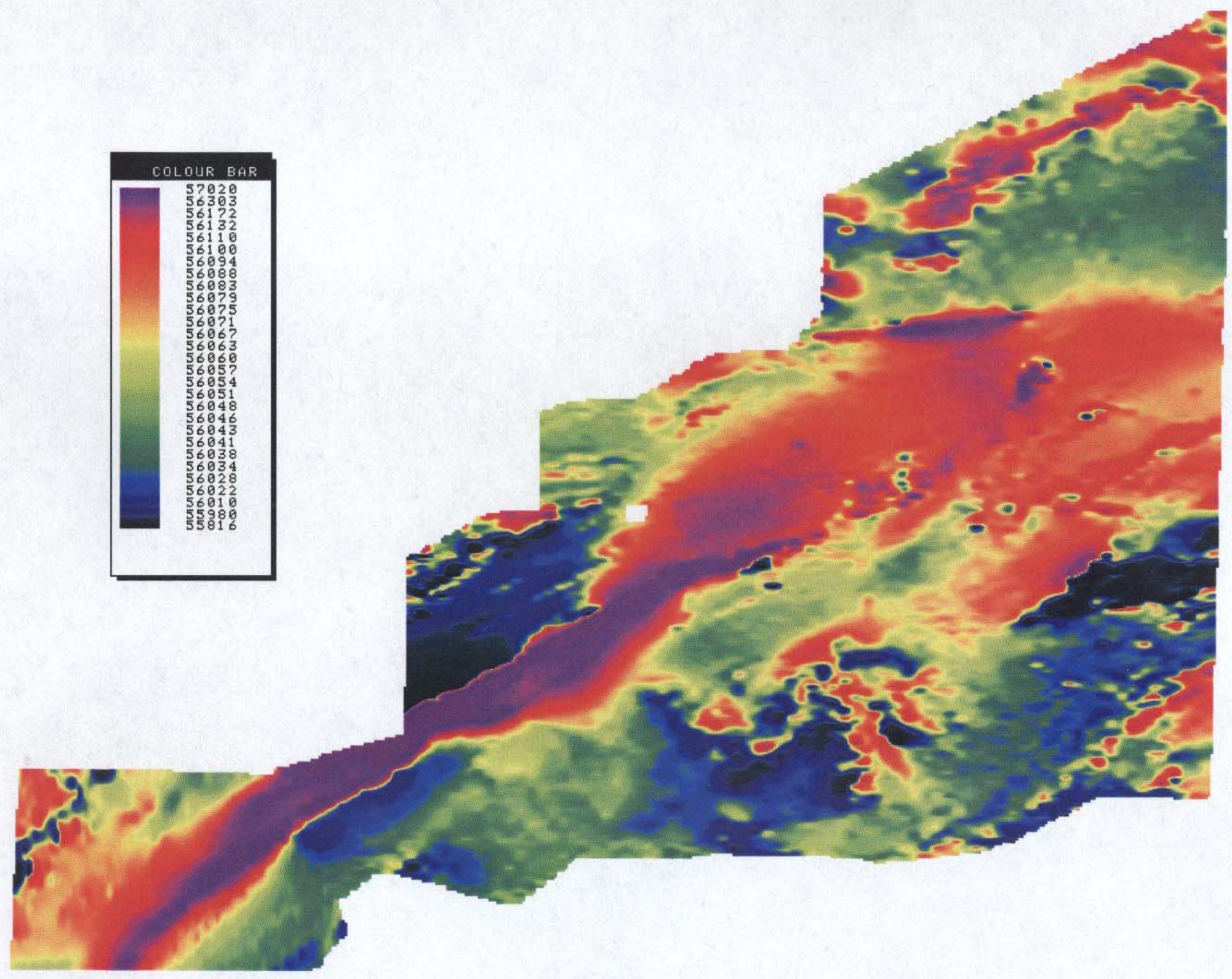

Figure 4b. Total field magnetics of the Broad Pass survey area and only a small part of the Chulitna survey. Magnetic units are in nT. Color scheme is an equal area distribution. 


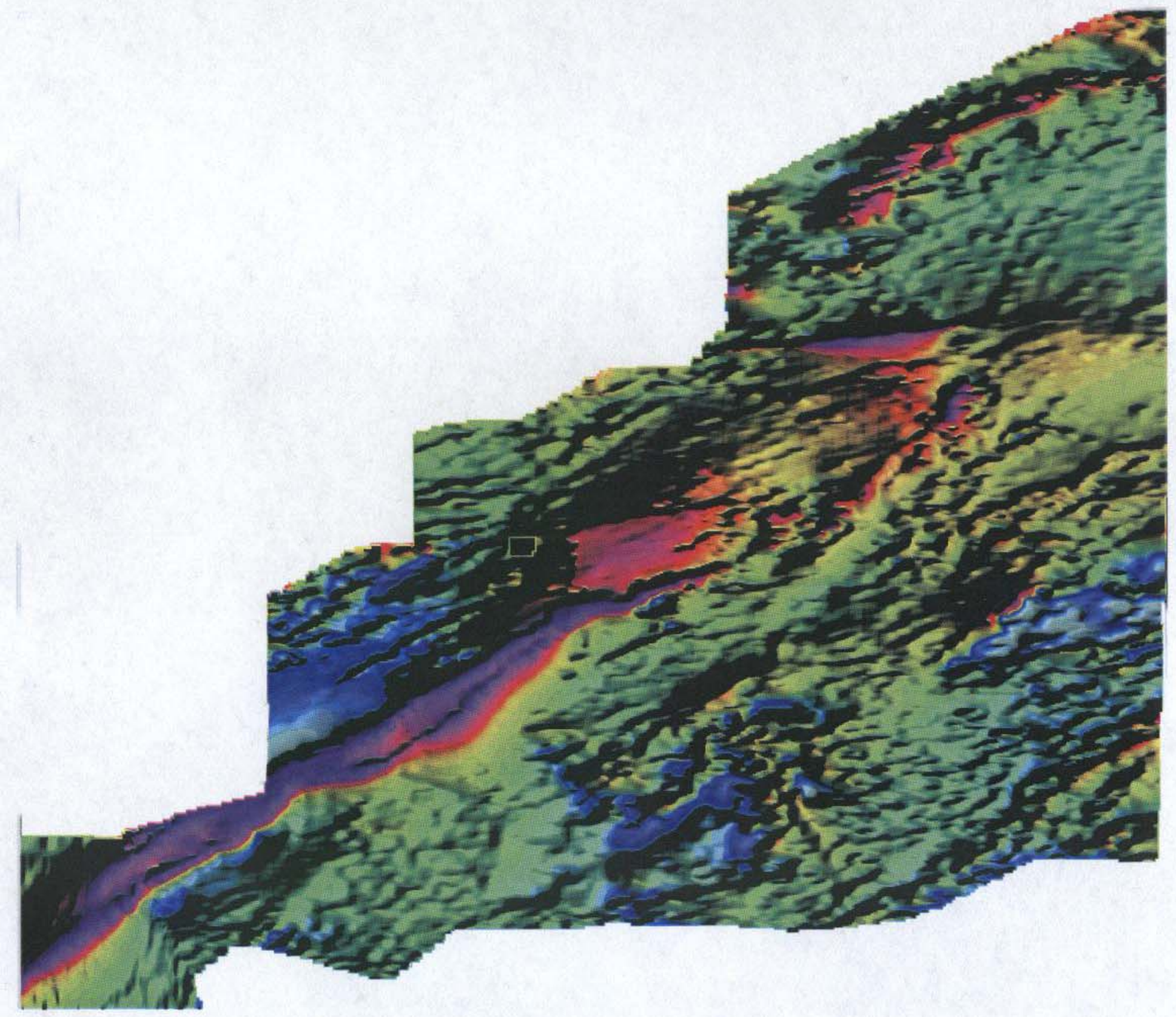

Figure 4c. Color shadow map of the total field magnetics of the southeastern extension of the Broad Pass area. Illumination is from the southeast. 


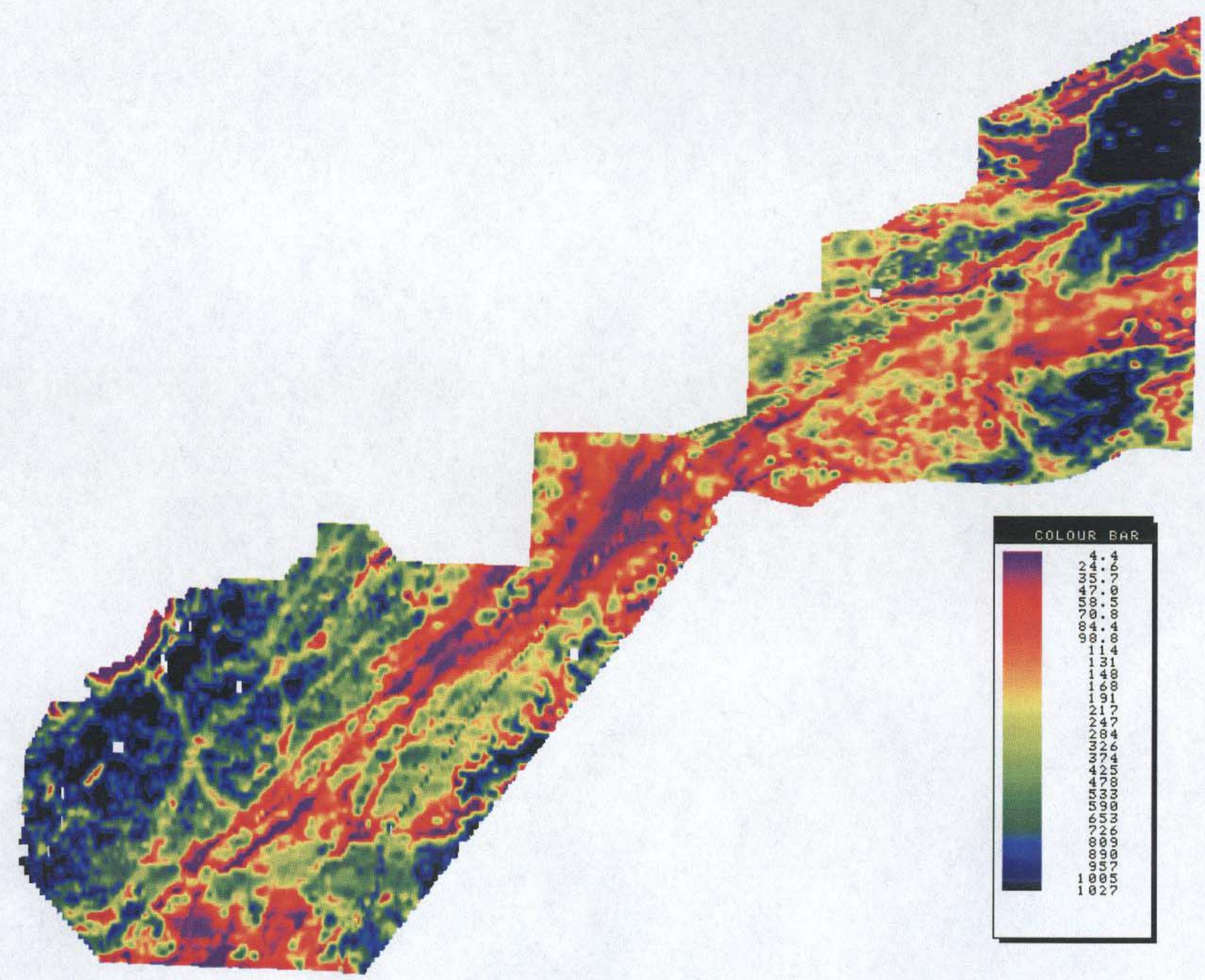

Figure 5a. $900 \mathrm{~Hz}$ coplanar resistivity of the Broad Pass and Chulitna survey areas. Resistivity units in ohm-m. Conductive units have low numbers and are shown in purple and orange on this map. An equal area color scheme is used. 


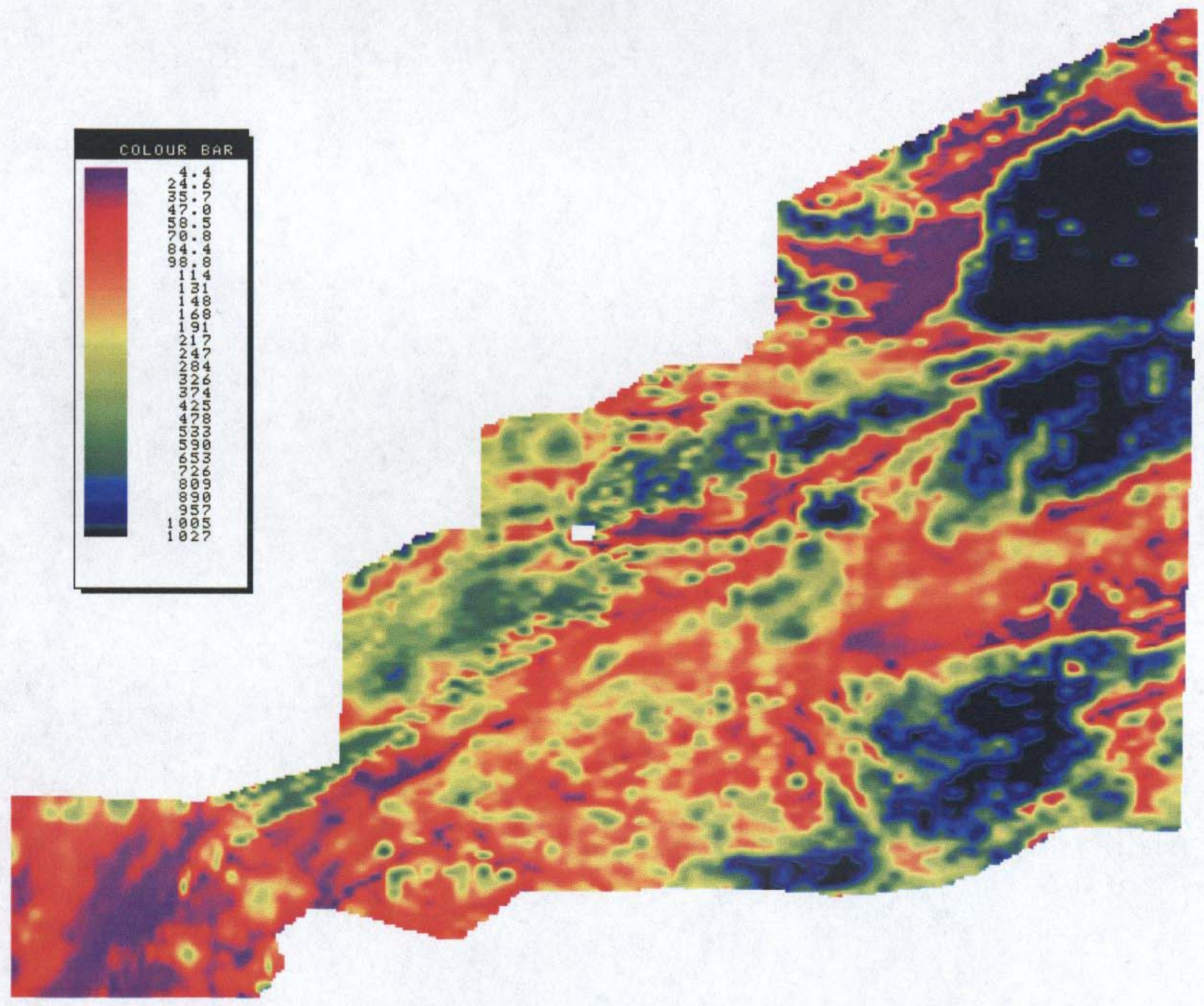

Figure 5 b. $900 \mathrm{~Hz}$ coplanar resistivity of the Broad Pass area and only a small part of the Chulitna survey. Resistivity units in ohm-m. Conductive units have low numbers and are shown in purple and orange on this map. An equal area color scheme is used. 


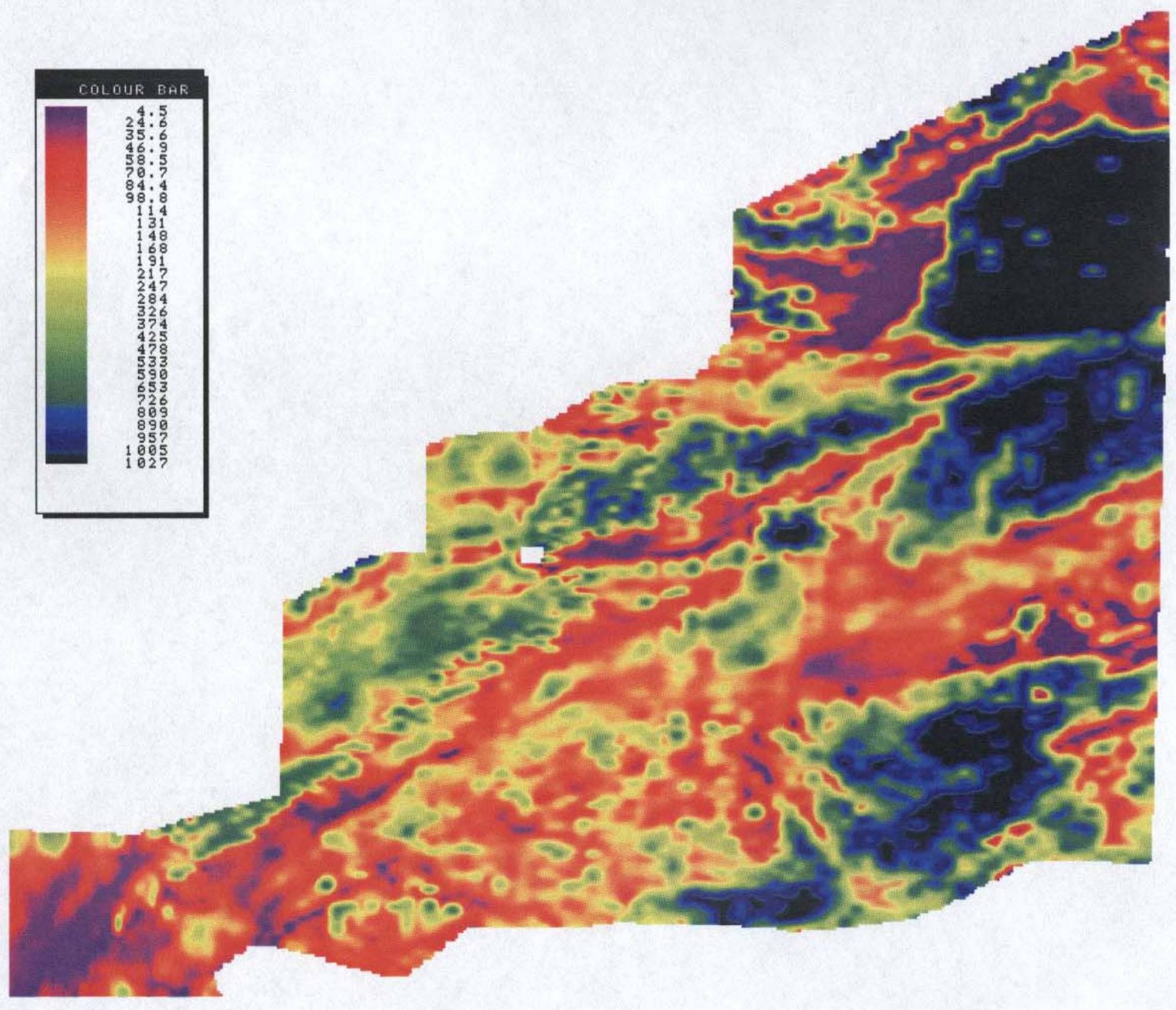

Figure 6. $7200 \mathrm{~Hz}$ coplanar resistivity of the Broad Pass area and only a small part of the Chulitna survey. Resistivity units in ohm-m. Conductive units have low numbers and are shown in purple and orange on this map. An equal area color scheme is used. 


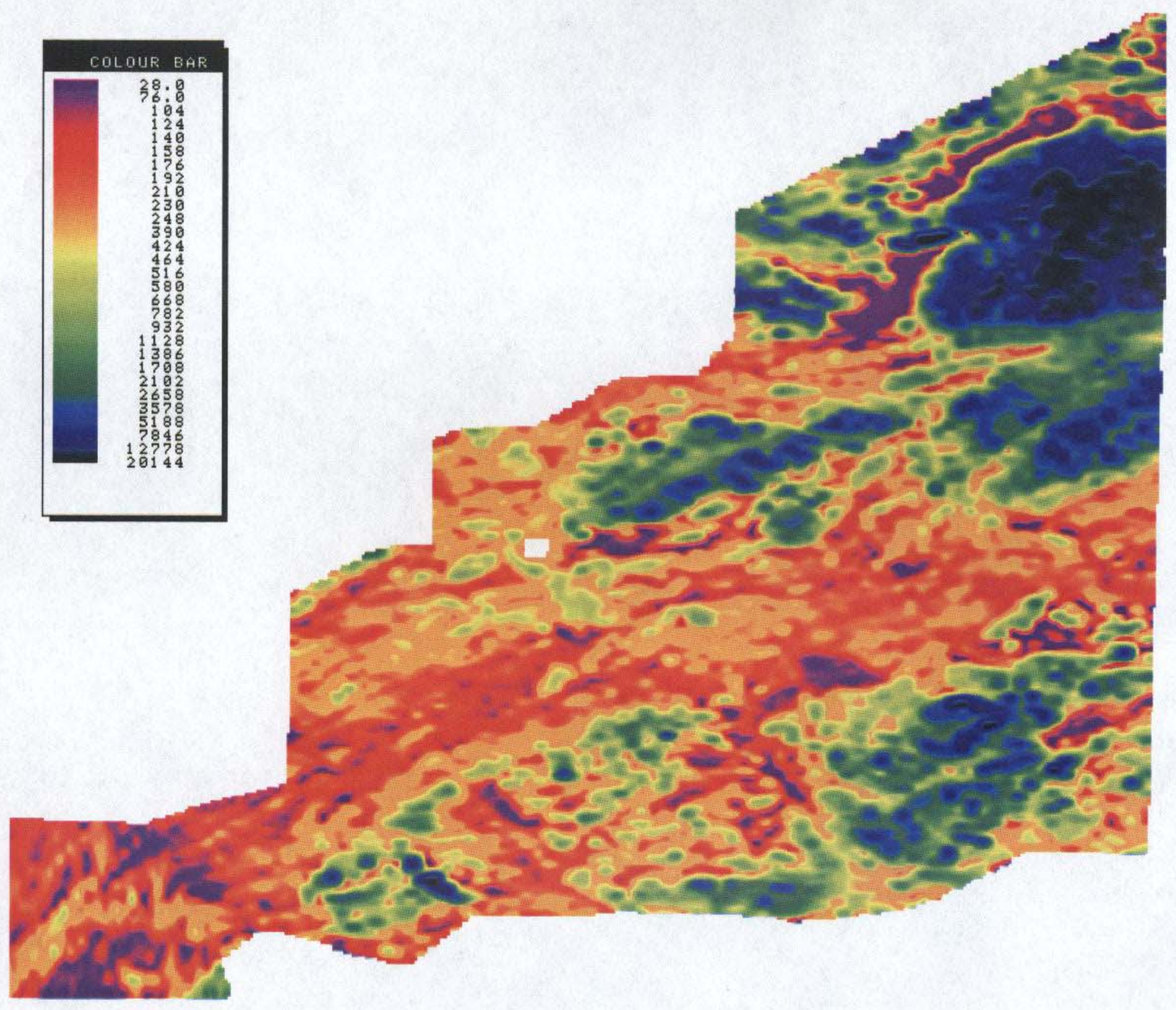

Figure 7: $56,000 \mathrm{~Hz}$ coplanar resistivity of the Broad Pass area and only a small part of the Chulitna survey. Resistivity units in ohm-m. Conductive units have low numbers and are shown in purple and orange on this map. An equal area color scheme is used. 